\title{
КЕРАМІЧНИЙ КОМПЛЕКС ПОХОВАНЬ ЗРУБНОЇ КУЛЬТУРИ ПІВНІЧНОГО ПРИАЗОВ'Я
}

Pеферат: У статті надано характеристику найбільш масовій категорії поховального інвентарю Зрубної культури Північного Приазов'я - керамічного посуду. В основу характеристики керамічного комплексу покладено морфологічні показники або функиіональні характеристики посуду. Визначено, що посуд зазнав певних якісних перетворень у просторі та часі, що виявили себе у формі та пропориіях предметів, рецепті глини, обробиі поверхні та орнаментуванні. Розглядаються деякі особливості обрядово-інвентарного комплексу $і$ питання культурно-хронологічної періодизачії поховальних пам'яток.

Ключові слова: бронзовий вік, доба пізньої бронзи, курган, зрубна культура, Північне Приазов'я, поховальний комплекс, керамічний посуд.

Глиняний посуд в рамках конкретних культурно-історичних утворень відрізняється певним консерватизмом і виступає в якості найбільш виразної їх ознаки. Вивчення форм i орнаментації значного числа зрубних посудин дозволяе виявити типологічні ряди, особливості та певні закономірності виготовлення похоронного керамічного посуду. В останні десятиліття XX ст. одночасно 3 масштабними польовими дослідженнями проводилася велика робота по первинному обліку, систематизації та класифікації керамічних комплексів з розкопок поселенських і поховальних пам'яток зрубної культури, у тому числі із застосуванням статистико-комбінаторних методів [Берестнев 2001; Бобринский 1986; 1988; Лопатин 1991; Семенова 2001; тощо].

З 1515 залучених для аналізу поховань зрубної культури Північного Приазов’я 274 $(18,1 \%)$ не мали жодного супровідного інвентарю. Однак 52 з них були зруйнованими або зафіксовані неналежним чином (переважно це стосується пам'яток, досліджених наприкінці XIX - початку XX ст.). Тому немає достатньо підстав говорити про безінвентарність всіх комплексів. Відтак кількість достовірно безінвентарних поховань зменшується до 222 (15,2\%). Цей показник зазнавав певних якісних змін в часі: простежується значне збільшення питомої ваги безінвентарних комплексів - 3 12,6\% у II горизонті до 22,8\% у III пізньому горизонті.

Одним з основних критеріїв культурної атрибуції пам'яток доби бронзи є керамічний посуд - найбільш масовий матеріал в поховальному інвентарі зрубної культури. У Північному Приазов’ї кераміку було виявлено в 1119 похованнях (82,5\% всіх незруйнованих могил). Розподіл поховань 3 керамічним посудом за горизонтами показав приблизно однакове поширення в часі цієї категорії реманенту (табл. 1).

Таблиця 1. Поховання з керамічним посудом за горизонтами

\begin{tabular}{|c|c|c|c|c|c|c|c|c|}
\hline & \multicolumn{2}{|c|}{ I горизонт } & \multicolumn{2}{c|}{ II горизонт } & \multicolumn{2}{c|}{ III горизонт } & \multicolumn{2}{c|}{ Всього } \\
\cline { 2 - 9 } & абс. & $\%$ & абс. & $\%$ & абс. & $\%$ & абс. & $\%$ \\
\hline $\begin{array}{c}\text { Поховання 3 } \\
\text { керамічним } \\
\text { посудом }\end{array}$ & 51 & 79,7 & 696 & 86,6 & 372 & 75,8 & 1119 & 82,5 \\
\hline $\begin{array}{c}\text { РАЗОМ } \\
\text { поховань за } \\
\text { горизонтами }\end{array}$ & 64 & 4,7 & 801 & 59,1 & 491 & 36,2 & 1356 & 100 \\
\hline
\end{tabular}

По одній посудині містили 980 поховань $(88,4 \%)$, по дві - 116 (10,5\%), по три - 9 $(0,8 \%)$, по чотири - 4 (0,3\%). Вдалося простежити деяку динаміку кількості керамічних посудин у похованні за горизонтами (табл. 2). При цьому зі 116 поховань 3 двома 
посудинами 10 були парними, що, відповідно, зменшує до 9,7\% долю захоронень 3 двома посудинами на одного небіжчика.

У розміщенні керамічних посудин в просторі поховання також відзначається певна варіативність. Так, у 23 випадках (1,9\%) зафіксовано розміщення посудин на перекритті могили. У двох випадках на перекритті знайдено по дві посудини, в 15 випадках посудини були як на перекритті, так і в самій могилі. У восьми випадках кераміку виявлено лише на перекритті безінвентарних поховань. Також відомі випадки розміщення кераміки на древньому горизонті в безпосередній близькості від поховання. Однак далеко не завжди знайдений в насипу посуд можна пов'язати з певним похованням.

Таблиця 2. Кількість керамічних посудин у похованні за горизонтами

\begin{tabular}{|c|c|c|c|c|c|c|c|c|c|c|}
\hline Посудини & & & & & & & & & $\mathrm{Bc}$ & \\
\hline Горизонт & абс. & $\%$ & абс. & $\%$ & абс. & $\%$ & абс. & $\%$ & абс. & $\%$ \\
\hline I горизонт & 40 & 81,6 & 9 & 18,4 & - & - & - & - & 49 & 100 \\
\hline II горизонт & 609 & 88,5 & 68 & 9,9 & 8 & 1,2 & 3 & 0,4 & 688 & 100 \\
\hline III горизонт & 331 & 89,0 & 39 & 10,4 & 1 & 0,3 & 1 & 0,3 & 372 & 100 \\
\hline PA3OM & 980 & 88,4 & 116 & 10,5 & 9 & 0,8 & 4 & 0,3 & 1109 & 100 \\
\hline
\end{tabular}

Різним було місце розміщення посудини всередині самої могили. Дослідниками виділяється чотири основні зони розміщення кераміки: «в головах», перед похованим, за ним, а також «в ногах». При цьому в кожній зоні виділяється кілька позицій, які, в свою чергу, мають кілька варіантів. Так, наприклад, в положенні посудини «перед похованим» виділяється п'ять основних позицій, три з яких мають свої варіанти [Полидович 1997, с. 163]. Нами було виділено п'ять основних зон місцеположення керамічних посудин щодо тіла небіжчика: I - перед головою (обличчям) і грудьми; II - біля живота; III - перед ногами нижче колін; IV - за головою і спиною вище тазу; V - позаду тазу і ніг.

Нам доступна інформація щодо 742 поховань, для яких можна здійснити зонування кераміки в могилі. У 626 випадках (84,3\%) кераміка розміщувалася в I зоні, в $19(2,6 \%)$ - в II зоні, в $19(2,6 \%)$ - в III зоні, в $73(9,8 \%)$ - в IV зоні, в 5 випадках $(0,7 \%)$ - в V зоні. Найхарактернішою для розміщення кераміки в приазовських зрубних похованнях $€$ I зона перед грудьми і головою. В переважній більшості кремацій посуд тяжів до південно-східного кута могильної споруди, тобто, враховуючи переважне східне орієнтування і лівобічне положення померлих, також розташовувався в зоні I. В комплексах, що містили дві посудини (72 поховання 3 можливістю зонування), кераміка розміщалася або в одній зоні разом (64\% випадків), або в різних зонах - окремо (36\% випадків). У похованнях, де посуд розміщувався разом, в переважній більшості випадків (89\%) керамічні ємності локалізувалися в зоні I поблизу голови або перед грудьми.

У чотирьох випадках посудини разом розташовувалися в зоні IV (за головою) і одного разу - в зоні III (навколо колін). Якщо ж посудини розміщалися окремо (26 випадків), то найчастіше вони локалізувалися перед небіжчиком - в зонах I і III (9 випадків) або I і II (2 випадки). В 10 комплексах посудини розміщено з протилежних сторін «в головах» (зони I і IV), в 3 комплексах - перед обличчям і за ногами (зони I i V), по разу - за спиною (зони V i IV) i у потилиці й колін (зони III i V). В комплексах, що містили три або чотири посудини, кераміка могла розміщуватися в різних позиціях і сполученнях, але завжди одна або дві посудини знаходилися перед обличчям небіжчика.

Аналіз розміщення керамічного посуду в похованнях за горизонтами також дозволив виявити хронологічні відмінності у розміщенні посудин в похованнях (табл. 3). Раніше зазначалось, що в курганах Північного Приазов’я, на відміну від басейну Сіверського Дінця, 
комплекси 3 покровськими пережитками стратиграфічно не виділяються в окремий горизонт, що може свідчити про порівняно пізню появу зрубної культури в Приазов’і [Литвиненко 1999, c. 14]. Попри цю обставину, слід звернути увагу на відмічені дослідниками певні відмінності у розміщенні посудин в покровських похованнях [Литвиненко 1994, с. 119-120; Мыськов 1991, c. 157]. Вирішальну роль при виділенні покровських комплексів на Сіверському Дінці зіграла кераміка. Розміщення посудин в могилах ПЗК відрізняється від поховань БМЗК. Саме локалізація посуду в похованнях є однією з рис відмінності між ПЗК і БМЗК [Отрощенко 2001, c. 153]. В покровських похованнях посудини, головним чином горщики й банки, часто стояли за головою, спиною, біля живота і біля ніг померлого [Литвиненко 1995, с. 73].

Таким чином, виділені зони місцеположення керамічних посудин щодо тіла померлого IIV можна визнати для поховальної практики носіїв зрубної культури Північного Приазов'я «неординарними». Також слід розглядати знаходження кераміки в цих позиціях в якості ознаки, що побічно вказує на приналежність комплексу до більш ранніх хронологічних горизонтів.

Таблиця 3. Розміщення однієї посудини в похованні по зонам за горизонтами

\begin{tabular}{|c|c|c|c|c|c|c|c|c|c|c|c|c|}
\hline Зона & \multicolumn{2}{|c|}{ I } & \multicolumn{2}{|c|}{ II } & \multicolumn{2}{|c|}{ III } & \multicolumn{2}{|c|}{ IV } & \multicolumn{2}{|c|}{$\mathrm{V}$} & \multicolumn{2}{|c|}{ Всього } \\
\hline Гор. & абс. & $\%$ & абс. & $\%$ & абс. & $\%$ & абс. & $\%$ & абс. & $\%$ & абс. & $\%$ \\
\hline I горизонт & 24 & 68,6 & - & - & 2 & 5,7 & 7 & 20,0 & 2 & 5,7 & 35 & 100 \\
\hline II горизонт & 392 & 83,2 & 15 & 3,2 & 15 & 3,2 & 47 & 10,0 & 2 & 0,4 & 471 & 100 \\
\hline III горизонт & 210 & 89,0 & 4 & 1,7 & 2 & 0,8 & 19 & 8,1 & 1 & 0,4 & 236 & 100 \\
\hline РА30M & 626 & 84,3 & 19 & 2,6 & 19 & 2,6 & 73 & 9,8 & 5 & 0,7 & 742 & 100 \\
\hline
\end{tabular}

В основі будь-якої археологічної класифікації і типології керамічних виробів лежить їх морфологічний аналіз. Досі не існує загальновизнаної методики такого аналізу, багато дослідників користуються своїми критеріями, причому основа для їх виділення може не збігатися, навіть якщо колекція вивчається одним дослідником. Відзначається, що подібна картина спостерігається вже на початку морфологічного аналізу - при вивченні форми окремої посудини [Горбов 2001]. Все це значно ускладнює порівняння опублікованих колекцій.

Керамічний комплекс зрубної культури Північного Приазов’я формують кілька типів посуду, що об'єднуються в групи за морфологічними показниками або функціональними ознаками. Раніше вже наголошувалося дослідниками, що жодна 3 існуючих типологій кераміки не може бути визнана універсальною, що змушує утриматися від їх застосування та використовувати спрощену, але загальноприйняту схему [Литвиненко 1994, с. 127]. Такою загальноприйнятою схемою може бути традиційне для зрубної культури, а також для близьких або генетично пов'язаних 3 нею культур, виділення т. зв. «керамічної тріади» - банок, гострореберних і округлобоких посудин [Горбов 2001, с. 29]. При цьому потрібно враховувати, що цими трьома провідними типами неможливо охопити все розмаїття кераміки, оскільки між зазначеними типами виділяються численні перехідні форми [Литвиненко 1994, с. 127].

В основу характеристики керамічного комплексу зрубної культури Північного Приазов'я покладено морфологічні показники посудин. Виділення груп здійснювалось за особливостями загальних пропорцій на підставі співвідношення метричних показників різних частин (співвідношення максимальної ширини тулуба та висоти посудини) 3 урахуванням позитивного досвіду попередників [Братченко 1976, с. 23-26; Бровендер 2000, с. 105-113; 309-315; Гершкович 1997, с. 125-144; Пробийголова 2017, с. 87-97; тощо].

Керамічний комплекс поділено на два класи в залежності від наявності або відсутності шийки: посуд 3 виділеною шийкою та посуд без шийки (рис. 1). Посуд з виділеною шийкою поділяється на два відділи: горщики та гострореберні посудини. Невисока шийка, відігнуті назовні вінця та виражені плічка, розташовані в верхній третині посудини, характеризують горшкоподібний посуд. В свою чергу горщики поділено на дві групи в залежності від 
показника співвідношення висоти посудини та найбільшого діаметра тулуба: високі діаметр тулуба менший за висоту посудини (тип А) та приземкуваті - діаметр тулуба більший за висоту посудини (тип Б).

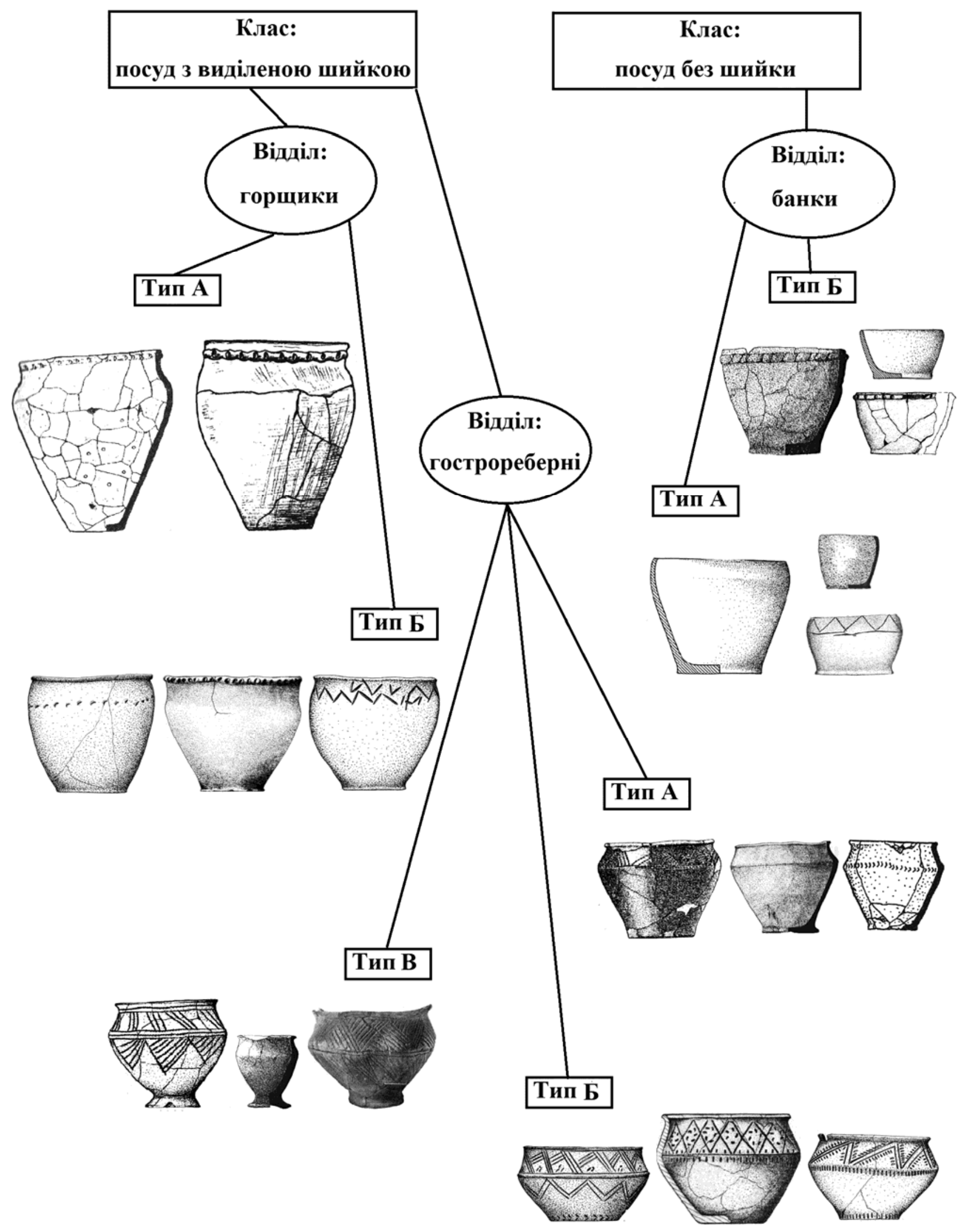

Рис. 1. Типологія керамічного комплексу

Fig. 1. Typology of the ceramic complex 
Посуд, віднесений до відділу гострореберні, також поділено на дві групи в залежності від показника співвідношення висоти посудини та найбільшого діаметра тулуба: гострореберний посуд струнких пропорцій - ребро-перегин в верхній третині тулуба (тип А) та гострореберний посуд низьких пропорцій - ребро-перегин в середній частині тулуба (тип Б). Нечисленний посуд, який характеризується високою шийкою, виразними плічками та наявністю полого піддона або ніжки, віднесено до групи кубків (тип В).

Клас посуду без шийки представлений банками, які, в свою чергу, в залежності від наявності або відсутності плічка поділено на дві групи: банки закриті - з наявними плічками зі стягнутим в середину краєм вінця (тип А) та банки відкриті - без плічка та з відігнутим назовні вінцем (тип Б).

Слід зазначити, що посуд, віднесений до всіх типів відділів обох класів, додатково може бути поділений на підтипи залежно від наявності / відсутності закраїни у дна або особливостей оформлення краю вінець.

Нами використано інформацію щодо 1388 керамічних посудин з курганних і грунтових могильників Північного Приазов'я. Переважна більшість кераміки походить власне 3 поховань, а 84 посудини - 3 насипів курганів. Через різний ступінь документованості залучених в роботі джерел та збереженості матеріалу за морфологічними показниками або функціональними ознаками було досліджено 1094 посудини. Типологічно керамічний комплекс Північного Приазов'я розподілений наступним чином: гострореберні посудини 459 (42,0\%); горщики - 287 (26,2\%); банки - 348 (31,8\%). 10 посудин з всього керамічного комплексу поховань Північного Приазов'я було віднесено до типу В відділу гострореберні кубки та кубкоподібні.

Розподіл типів керамічного комплексу за горизонтами відбито у таблиці (табл. 4) та відображено на схемі (рис. 2). Так, для найбільш ранніх поховань 3 покровськими рисами та комплексів II розвиненого горизонту відмічено приблизно однакове співвідношення типів посудин: гострореберні посудини - відповідно 48,0\% і 48,0\%, горщики - 26,0\% і 22,7\%; банки $-26,0 \%$ і $28,9 \%$. Однак у похованнях III пізнього хронологічного горизонту відносно рідкісними є посудини гострореберних форм (28\%). При відносно високому відсотку банок $(38,4 \%)$ звертає на себе увагу значна кількість різноманітних горщиків.

Таблиця 4. Розподіл типів керамічного комплексу за горизонтами

\begin{tabular}{|c|c|c|c|c|c|c|c|c|}
\hline & \multicolumn{2}{|c|}{ Гострореберні } & \multicolumn{2}{|c|}{ Горщики } & \multicolumn{2}{c|}{ Банки } & \multicolumn{2}{c|}{ Всього } \\
\cline { 2 - 9 } & Абс. & $\%$ & Абс. & $\%$ & Абс. & $\%$ & Абс. & $\%$ \\
\hline I горизонт & 26 & 48,0 & 14 & 26,0 & 14 & 26,0 & 54 & 4,9 \\
\hline II горизонт & 333 & 48,4 & 156 & 22,7 & 199 & 28,9 & 688 & 62,9 \\
\hline III горизонт & 100 & 28,4 & 117 & 33,2 & 135 & 38,4 & 352 & 32,2 \\
\hline РАЗОМ & 459 & 42,0 & 287 & 26,2 & 348 & 31,8 & 1094 & 100 \\
\hline
\end{tabular}

Розподіл посуду без шийки (відкритих та закритих банок) окремо за горизонтами (табл. 5) також дозволив виявити тенденцію поступового збільшення питомої ваги відкритих банок и, навпаки, зменшення закритих банок від I до III горизонту (рис. 3).

Таблиця 5. Розподіл відкритих та закритих банок за горизонтами

\begin{tabular}{|c|c|c|c|c|c|c|}
\hline & \multicolumn{2}{|c|}{ відкриті } & \multicolumn{2}{c|}{ закриті } & \multicolumn{2}{c|}{ Всього } \\
\cline { 2 - 7 } & Абс. & $\%$ & Абс. & $\%$ & Абс. & $\%$ \\
\hline I горизонт & 8 & 57,1 & 6 & 42,9 & 14 & 4,0 \\
\hline II горизонт & 138 & 69,3 & 61 & 30,7 & 199 & 57,2 \\
\hline III горизонт & 105 & 77,8 & 30 & 22,2 & 135 & 38,8 \\
\hline РАЗОМ & 251 & 72,1 & 97 & 27,9 & 348 & 100 \\
\hline
\end{tabular}




\section{I горизонт}

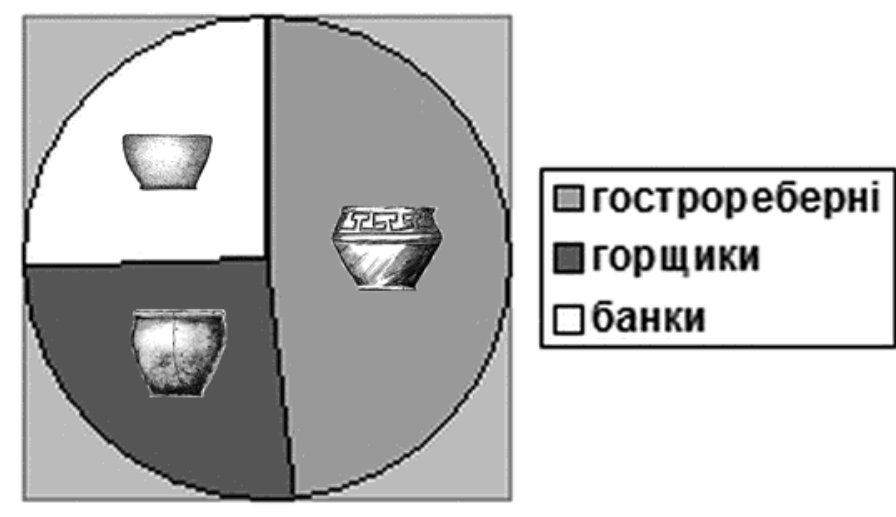

\section{II горизонт}

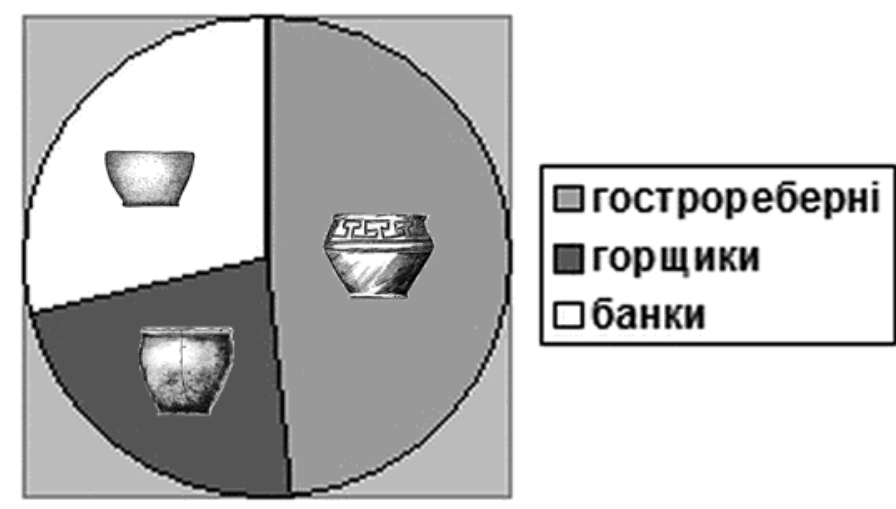

III горизонт

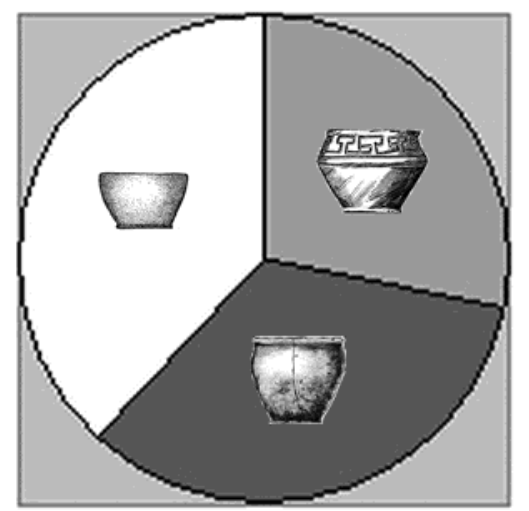

Рис. 2. Діаграма. Розподіл типів керамічного комплексу за горизонтами

Fig. 2. Diagram. Distribution of types of ceramic complex by horizons

Орнаментальні композиції, що зустрічаються на керамічних посудинах 3 поховань зрубної культури Північного Приазов'я, демонструють надзвичайну варіативність та заслуговують окремої уваги. Даній темі присвячено цілий ряд публікацій, у тому числі монографічного характеру. При цьому дослідниками розглядаються різні аспекти проблематики. Орнамент розглядається не тільки з метою розробки класифікації орнаментальних композицій, вивчення культурогенези й культурних зв'язків, а також для встановлення вузької хронології пам'яток. Аналіз особливостей орнаментації кераміки Північного Приазов'я (різних елементів і їх поєднання) і способів іiі нанесення також дозволяє виявити деякі хронологічні тенденції.

Орнаментація посуду в залежності від техніки нанесення елементів може бути штампованою, прокресленою або рельєфною. Орнамент представлений композиціями з:

1. відбитків мотузки;

2. перевитого шнура;

3. зубчастого штампу (великого та дрібного);

4. відбитків торця палички;

5. нігтьових відбитків або пальцевих вдавлень;

6. відбитків порожнистої палички;

7. прокреслених (прорізаних) елементів;

8. валиків.

Орнаментальні геометричні композиції виконані за допомогою вищеозначених елементів у вигляді косих хрестів, рівнобедрених трикутників вершинами до низу або вгору (іноді заштрихованих), «драбинок», меандрів, зигзагів, бахроми з насічок («війки»), а також паралельних горизонтальних ліній під віночком i на плічках. Відомий іррегулярний орнамент в прокресленій техніці, а також у вигляді відбитків, виконаних торцем палички (похилі лінії, трикутники, хрести, ромби, зиґзаги тощо). Для складних композицій характерно поєднання основної та бордюрної зони.

Рельєфна орнаментація репрезентована наліпним валиком (36 випадків) та двома валиками (8 випадків) на шийці або на плічках посудини. В оформленні валика також простежується незначна варіативність:

В1 - гладкий валик;

В2 - відбитки пальців/нігтів;

В3 - навскісні насічки торцем палички. 


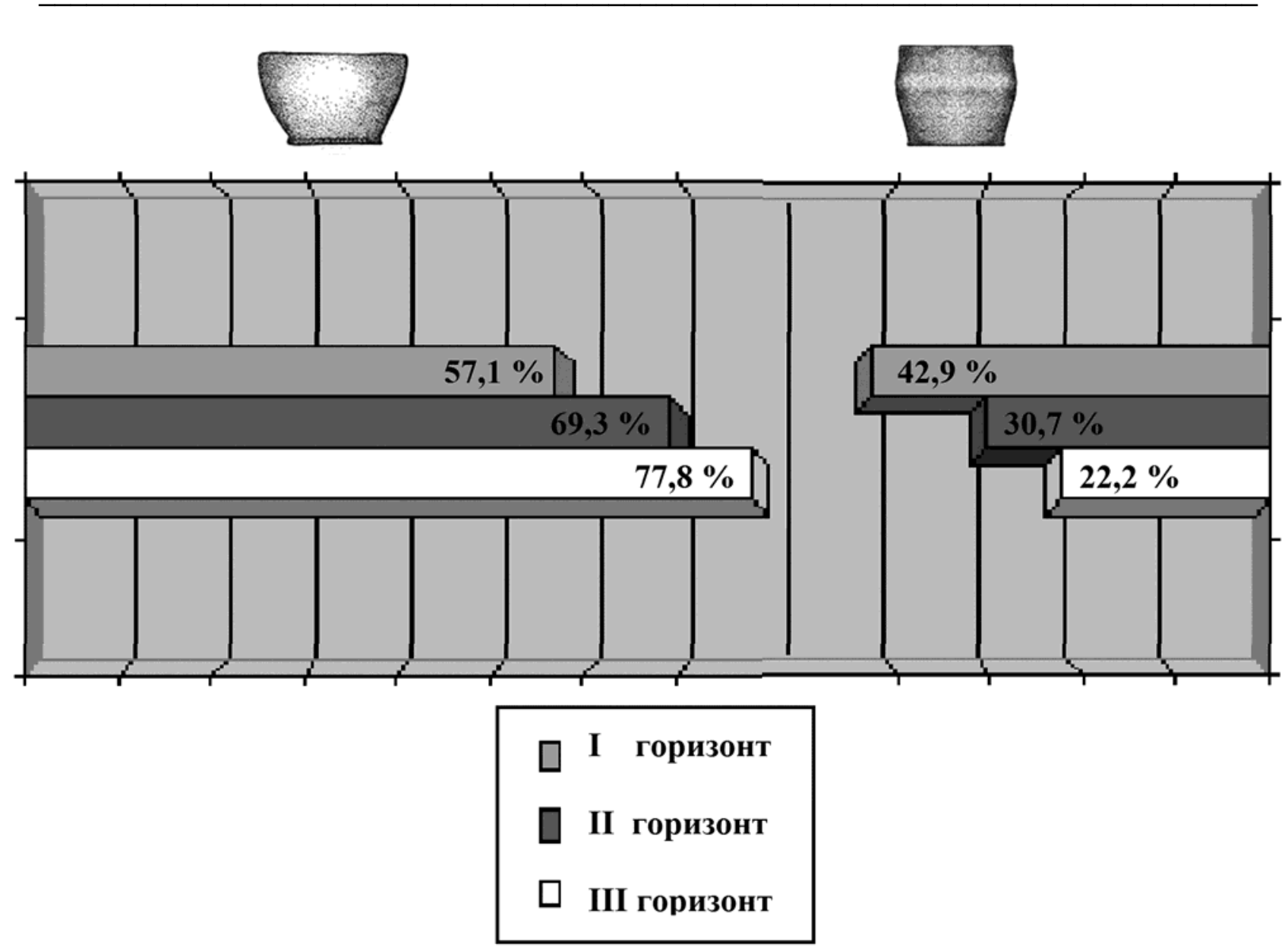

Рис. 3. Діаграма. Розподіл відкритих та закритих банок за горизонтами Fig. 3. Diagram. Distribution of open and closed jars by horizons

У приазовських похованнях дослідниками відзначається збільшення долі орнаментації наліпним валиком, попри загальну іiі нечисленність, порівняно, наприклад, зі Степовим Подніпров'ям і Передстепом [Литвиненко 1999, с. 17]. Вже зверталася увага на тенденцію збільшення питомої ваги оздоблення керамічного посуду гладкими та карбованими валиками в зрубних могильниках при русі в південно-західному і західному напрямках, i навпаки [Ковалева 1997, с. 11; Литвиненко 1999a, с. 100; Отрощенко 2006, с. 25-26, 27; тощо], що може свідчити про успадкування населенням БМЗК від своїх бабинських пращурів вказаної традиції. Ця обставина підтверджується такими даними: на Сіверському Дінці посудини 3 валиком складають 2,8\% керамічної серії, в Приазов'ї - 5,5\%, в Степовому Подніпров'ї 10,8\% [Литвиненко 1999a, с. 100]. Картографія комплексів зрубної культури Північного Приазов'я, що містять керамічні форми з орнаментацією наліпним валиком, дозволила нам наочно (враховуючи нерівномірність насиченості досліджуваного регіону дослідженими пам’ятками) підтвердити намічену раніше тенденцію (рис. 4).

3 урахуванням позитивного досвіду попередників [Литвиненко 1999, с. 4-23] вдалося простежити й певні якісні зміни в просторі й в часі, що проявлялися у формі і пропорціях посудин керамічного комплексу Північного Приазов'я, складі тіста, обробці поверхні й орнаментації.

Керамічний комплекс I хронологічного горизонту характеризується наявністю значної кількості домішок в тісті посудин (крупнозернистий пісок, товчена мушля, шамот), використанням для вирівнювання поверхні крупного зубчастого штампу, трави або тріски, що залишали глибокі розчоси на поверхні. Для посудин цього горизонту типовою $\epsilon$ «паркетна» обробка поверхні. Обпалювання часто нерівномірне, 3 різнокольоровими перепаленими плямами і слідами від нагару. Гострореберний посуд характеризується 
виразним переломом посередині або у верхній третині висоти, який утворює гостре ребро. Для керамічного комплексу цього хронологічного горизонту характерний відігнутий назовні край вінця, який надає профілю схожість 3 дзвоном. У той же час на шийці простежується наявність внутрішнього ребра-уступу. Гострореберний посуд, а також банки нерідко орнаментовані по зрізу або внутрішній поверхні вінця, інколи мають закраїни у дна. Посуд у верхній третині прикрашено відбитками зубчастого штампу, перекрученого шнура, косими насічками, виконаними торцем палички і в прокресленій техніці. Орнамент - геометричні композиції у вигляді косих хрестів, які перехрещуються, рівнобедрених трикутників вершинами донизу (іноді заштрихованих), зиґзагів, бахроми 3 насічок («війки»), а також паралельні горизонтальні лінії під віночком і на плічках. Для банок характерно нанесення іррегулярного орнаменту в прокресленій техніці, а також у вигляді відбитків, виконаних торцем палички (похилі лінії, трикутники, хрести, ромби, зигзаги тощо).

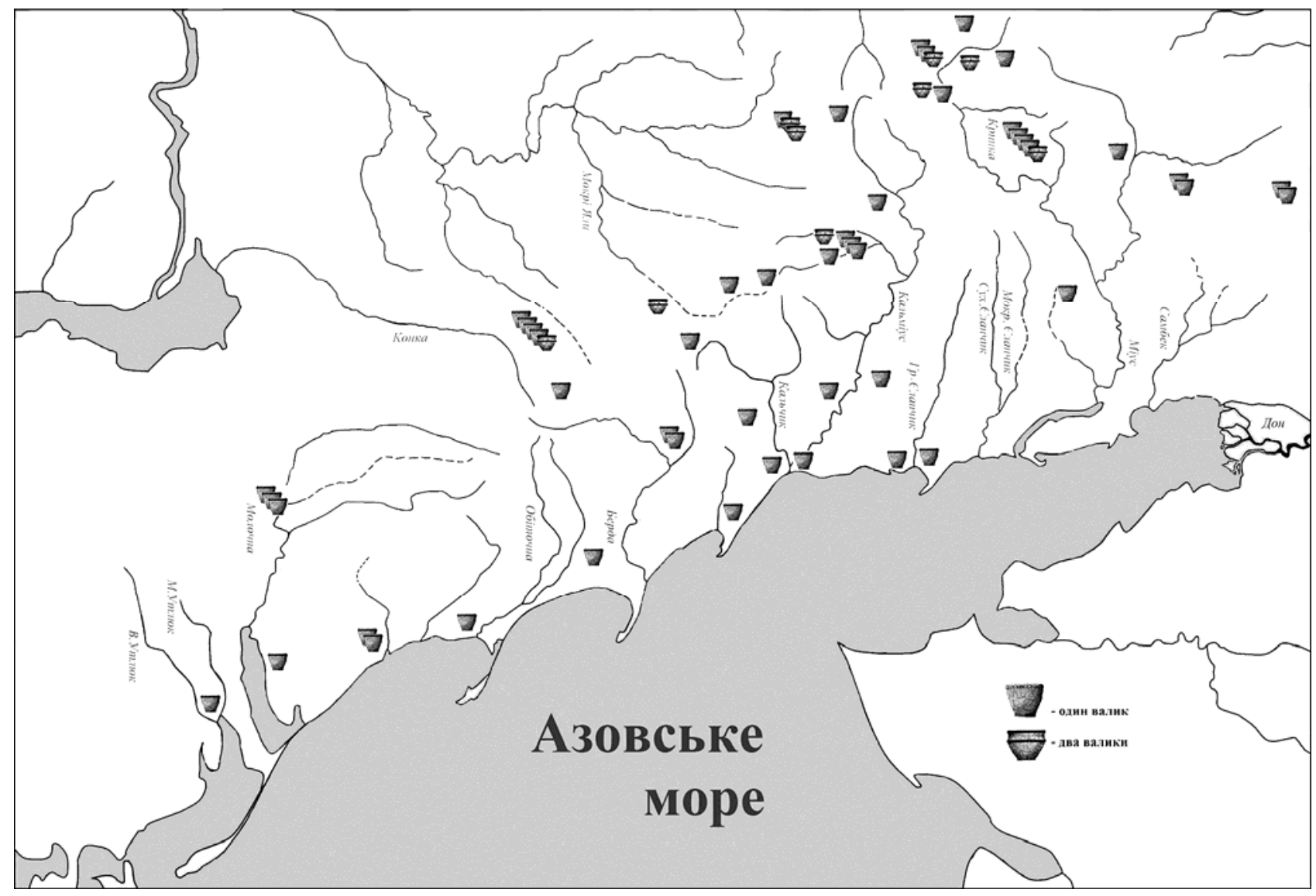

Рис. 4. Карта поширення кераміки з орнаментацією наліпним валиком

Fig. 4. Distribution map of pottery with a relief ornamentation

У керамічному комплексі II хронологічного горизонту, як і раніше, наявна значна кількість домішок в тісті посудин (крупнозернистий пісок, шамот, жорства, товчена мушля зустрічається рідше). З'являються керамічні посудини асиметричних форм. На зовнішній поверхні періодично простежено сліди від лощіння або загладжування, різнокольорові плями неякісного випалу і сліди від нагару. Зберігається традиція вирівнювання поверхні зубчастим штампом, травою або тріскою. Паркетна обробка поверхні дрібнозубчастим штампом трапляється зрідка. Гострореберний посуд характеризується виразним переломом у верхній третині висоти, який утворює гостре ребро, з'являється чимало неорнаментованих гострореберних посудин і близьких їм форм. Дещо зростає питома вага орнаментальних композицій, виконаних прокреслюванням. Зубчастий штамп і відбитки шнура у техніці декору майже зникають. Для керамічного комплексу цього хронологічного горизонту 
зберігається практика орнаментації по зрізу або внутрішній поверхні вінця. Зростає кількість посуду, прикрашеного закраїнами у дна, та питома вага «відкритих» банок зі слабко виділеною шийкою і відігнутим вінцем. У декорі посудин поширення набувають такі орнаментальні мотиви, як меандр, трикутний паркет, свастичні символи, складні горизонтальні композиції тощо. Заявляється посуд, прикрашений по всій площі геометричними композиціями. Продовжують використатись такі орнаментальні мотиви, як хрести, рівнобедрені трикутники (вершинами догори і донизу), зигзаги, бахрома з насічок (війки), а також паралельні горизонтальні лінії під вінцями і на плічках. 3'являється рельєфна орнаментація посуду (як посудин гострореберних форм, так і банок) одинарним валиком під краєм вінця та на плічках.

Керамічна серія III хронологічного горизонту курганних. У якості домішок в тісті посудин використовується дрібний пісок, шамот, жорства. Великозернистий пісок і товчена мушля майже зникають. Питома вага керамічних посудин асиметричних форм зростає. Обробка поверхні дрібнозубим штампом зникає. Досить часто трапляється лискування зовнішньої поверхні посуду. Гострореберний посуд характеризується поступовим огрубінням, згладженими ребрами, спрощенням та поступовим зникненням орнаментації. Класичні банки поступаються місцем різним слабо профільованим типам горщиків круглобоких форм, що характеризуються плавно відігнутими невисокими вінцями, м'яким перегином у верхній третині посудини, грубо сформованою закраїною у дна. Особливого поширення в цей період набуває рельєфна орнаментація посуду одинарними (рідше двома) наліпними напівкруглими або овальними в перетині валиками під краєм вінця та на плічках. Зазвичай валики прикрашені відбитками пальців/нігтів, відбитками різноманітних штампів, косими насічками, виконаними торцем палички. Заглиблений орнамент (відбитки штампу, пальців/нігтів, прокреслені лінії тощо) співіснує в цей період з рельєфною орнаментацією посуду. У декорі посудин зберігаються спрощені орнаментальні мотиви, такі як паралельні прокреслені горизонтальні лінії, заглиблені композиції у вигляді поясу похилих насічок або відбитків нігтів під вінцями і на плічках. Відомі композиції з трикутників вершинами донизу, трикутників без основи, простих одинарних зигзагів.

В цілому, керамічний посуд зазнавав певні якісні зміни в просторі і в часі, що проявлялися у формі і пропорціях посудин, складі тіста, обробці поверхні й орнаментації. Орнаментальні композиції на керамічних посудинах 3 поховань зрубної культури демонструють певну варіативність за рахунок комбінування обмеженої кількості відносно простих елементів (валику, зигзагу, вдавлень, трикутників, хрестів, ромбів тощо).

Забавин В.О.

\section{КЕРАМИЧЕСКИЙ КОМПЛЕКС ПОГРЕБЕНИЙ СРУБНОЙ КУЛЬТУРЫ СЕВЕРНОГО ПРИАЗОВЬЯ}

В статье дана характеристика керамического комплекса погребений срубной культуры Северного Приазовья. Сделан анализ некоторых особенностей обрядово-инвентарного комплекса, рассмотрены вопросы культурно-хронологической периодизации приазовских погребальных памятников. Комплекс материальных останков, добытых в ходе археологического исследования курганных некрополей и поселенческих памятников, рассматривается в качестве основного источника для изучения культуры, хозяйства и быта племен, населявших регион в эпоху бронзы. Корпус артефактов срубной культуры Северного Приазовья - керамическая посуда, изделия из цветных металлов, кости, дерева и камня. Наиболее массовый погребальный материал - глиняная посуда, которая в рамках конкретного культурно-исторического образования наделена определенным консерватизмом и является наиболее выразительным его внешним признаком. Анализ размещения керамической посуды в погребениях по горизонтам также позволил выявить хронологические различия в размещении сосудов в погребениях. Для погребальной практики носителей срубной культуры Северного Приазовья некоторые зоны местоположения керамических сосудов относительно тела умершего можно признать «неординарными». Нахождение в этих зонах керамики 
также следует рассматривать в качестве признака, который косвенно может указывать на более раннюю хронологическую позицию конкретного комплекса. В основу характеристики керамического комплекса срубной культуры Северного Приазовья положены морфологические показатели сосудов. Выделение групп осуществлялось по особенностям общих пропорций на основании соотношения метрических показателей различных частей. Изучение пропорций, форм и орнаментальных композиций значительного в количественном отношении керамического корпуса позволило определить типологические ряды, а также говорить об особенностях и определённых закономерностях изготовления погребальной посуды срубной культуры Северного Приазовья. Учитывая положительный опыт предшественников, удалось проследить определенные качественные изменения в пространстве и во времени, проявлявшиеся в форме и пропорциях сосудов, составе теста, обработке поверхности и орнаментации. Разнообразие орнаментальных композиций, встречающихся на приазовской погребальной керамике, характеризуется значительной вариативностью, что достигается путем сочетания незначительного числа сравнительно простых элементов.

Ключевые слова: Северное Приазовье, срубная культура, эпоха поздней бронзы, погребение, керамический комплекс.

Zabavin $V$.

\section{FUNERARY CERAMIC COMPLEX OF ZRUBNA CULTURE OF NORTHEN AZOV}

The article presents the characteristics of the most frequent category of the funerary inventory of the Zrubna culture (Srubnaya culture, Timber-grave culture) of the Northern Azov Sea region (Late Bronze Age) that is of pottery. The basis of the ceramic complex characterization was morphological indices or functional characteristics of the items. It was determined that crockery underwent certain qualitative transformations in space and time that revealed themselves in the form and proportion of the items, clay recipe, surface processing and ornamentation. Questions of the internal periodization and some special features of ritual inventory complex are examined. The main source for the study of culture, life and economy of the tribes of the Bronze Age are the material remains, obtained during archaeological investigations of domestic settlements and funerary monuments. Corpus of artifacts include pottery, stone, bone, flint, wood and nonferrous metals. Ceramic vessels within specific cultural and historical formations are differ conservatism. Pottery stands as the most expressive of their external features. The study of ornamentation and forms of a significant number of vessels of Timber-Grave culture allows revealing typological series, features and certain patterns of manufacturing funerary ware. The predominance of plant memorial food in the burials suggests that agriculture played a significant role in the economic balance of the tribes of Timber-Grave culture of Northern Azov. Indirectly, being in one of the female burials of Timber-Grave culture of Northern Azov of some seeds can also testify about it. Some positions the location of ceramic vessels relative to the body of the deceased can be considered «extraordinary» for the burial practices of tribes of Timber-Grave culture of Northern Azov. It should also to consider the presence of ceramic vessels in these positions as a feature, indirectly indicating the belonging of the complex to the earlier chronological horizons. In general, ceramic pottery has undergone some qualitative changes in space and time. These changes are manifested in the form and proportions of vessels, consisting of clay, surface treatment and ornamentation. Ornamental compositions, which are found on ceramic vessels from Timber-Grave culture burials, demonstrate the extraordinary variability, although their diversity is achieved by combining a small number of relatively simple characters.

Keywords: Bronze Age, Zrubna culture, Timber-grave culture, Northern Azov Sea region, funeral complexes, pottery, ceramic complex.

\section{СПИСОК ДЖЕРЕЛ ТА ЛІТЕРАТУРИ}

Берестнев С.И. Восточноукраинская лесостепь в эпоху средней и поздней бронзы (II тыс. до н.э.). - Харьков, 2001. -264 с.

Бобринский А.А. О методике изучения форм глиняной посуды из археологических раскопок // Культуры Восточной Европы I тысячелетия. - Куйбышев, 1986. - С. 137-157.

Братченко С.Н. Нижнее Подонье в эпоху средней бронзы. - К., 1976. - 251 с. 
Бровендер Ю.М. Поселення зрубної спільності в середній течії Сіверського Дінця: дис. ... канд. ист. наук. - К., 2000. - НА ІА НАНУ. - Ф. 12. - Оп. 2. - № 810. - 486 с.

Гершкович Я.П. Происхождение и эволюция сабатиновского керамического комплекса // АA. - Вып. 6. - Донецк, 1997. - С. 125-144.

Горбов В.Н. О наименовании частей сосудов позднего бронзового века // Эпоха бронзы ДоноДонецкого региона. - Киев; Воронеж, 2001. - С. 29-32.

Ковалёва И.Ф. Соотношение культуры многоваликовой керамики и срубной в Днепровском Предстепье // Сабатиновская и срубная культуры: проблемы взаимосвязей востока и запада в эпоху поздней бронзы. - К.; Николаев; Южноукраинск, 1997. - С. 10-11.

Литвиненко Р.А. Срубная культура бассейна Северского Донца (по материалам погребальных памятников): дис. ... канд. ист. наук. - К., 1994. - НА ІА НАНУ. - Ф. 12. - Оп. 2. - № $750 .-345$ с.

Литвиненко Р.А. Памятники покровского типа на Северском Донце // Археологические вести. СПб., 1995. - № 4. - С. 73-82.

Литвиненко Р.А. Периодизация срубных могильников Северо-Восточного Приазовья // Древности Северо-Восточного Приазовья. - Донецк, 1999. - С. 4-23.

Литвиненко Р.А. К истории исследования курганных могильников в окрестностях Каменных Могил // Древности Северо-Восточного Приазовья. - Донецк, 1999а. - С. 98-101.

Лопатин В.А. Классификация керамики Преображенского поселения // АВЕС. - Вып. 2. Саратов, 1991. - С. 42-52.

Мыськов Е.П. К проблеме периодизации памятников срубной культуры Нижнего Поволжья и Волго-Донского междуречья // СА. - 1991. - №4. - С. 145-163.

Отрощенко В.В. Проблеми періодизації культур середньої та пізньої бронзи Півдня Східної Європи (культурно-стратиграфічні зіставлення). - К., 2001. - 288 с.

Отрощенко В.В. До генези бережнівсько-маївської зрубної культури // Проблеми гірничої археології: Матеріали III-го Картамиського польового археологічного семінару (с. Новозванівка Луганської обл., 15.07.2004 р.). - Алчевськ, 2006. - С. 18-30.

Пробийголова О.С. Населення нижньої течії Сіверського Донця та Донецького кряжу у заключний період доби пізньої бронзи: дис. ... канд. ист. наук. - К., 2017. - НА ІА НАНУ. - Ф. 12. Оп. 2. -314 c.

Полидович Ю.Б. О размещении керамических сосудов в срубных погребениях // АА. - Вып. 6. - Донецк, 1997. - С. 163-172.

Семенова А.П. Основные тенденции развития керамики покровского и развитого этапов срубной культуры лесостепного Поволжья (по данным погребальных памятников) // Бронзовый век Восточной Европы: характеристика культур, хронология и периодизация. - Самара, 2001. - С. 273 279.

\section{REFERENCES}

Berestnev S.I. Vostochnoukrainskaya lesostep' v epohu srednej i pozdnej bronzy (II tys. do n.e.) [Eastern Ukrainian forest-steppe in the Middle and Late Bronze Age (II millennium BC)]. - Har'kov, 2001. $264 \mathrm{~s}$.

Bobrinskij A.A. O metodike izucheniya form glinyanoj posudy iz arheologicheskih raskopok [On the methodology for studying the forms of pottery from archaeological excavations] // Kul'tury Vostochnoj Evropy I tysyacheletiya. - Kujbyshev, 1986. - S. 137-157.

Bratchenko S.N. Nizhnee Podon'e v epohu srednej bronzy [Lower Don region in the Middle Bronze Age]. - K., 1976. - $251 \mathrm{~s}$.

Brovender Yu.M. Poselennia zrubnoi spilnosti v serednii techii Siverskoho Dintsia [Settlements of the Zrubna culture community in the middle reaches of the Seversky Donets]: dys. ... kand. yst. nauk. - K., 2000. - NA IA NANU. - F. 12. - Op. 2. - № 810. - 486 s.

Gershkovich YA.P. Proiskhozhdenie i evolyuciya sabatinovskogo keramicheskogo kompleksa [The origin and evolution of the ceramic complex of the Sabatinovka culture] // AA. - Vyp. 6. - Doneck, 1997. S. 125-144.

Gorbov V.N. O naimenovanii chastej sosudov pozdnego bronzovogo veka [About the title of the parts of pottery of the late Bronze Age] // Epoha bronzy Dono-Doneckogo regiona. - Kiev; Voronezh, 2001. - S. 29-32. 
Kovalyova I.F. Sootnoshenie kul'tury mnogovalikovoj keramiki i srubnoj v Dneprovskom Predstep'e [The correlation of the Mnogovalikovay culture and the Srubnaya culture in the Dnieper pre-steppe region] // Sabatinovskaya i srubnaya kul'tury: problemy vzaimosvyazej vostoka i zapada v epohu pozdnej bronzy. K.; Nikolaev; YUzhnoukrainsk, 1997. - S. 10-11.

Litvinenko R.A. Srubnaya kul'tura bassejna Severskogo Donca (po materialam pogrebal'nyh pamyatnikov) [The Srubnaya Culture of the Seversky Donets Basin (based on materials of funerary monuments)]: dis. ... kand. ist. nauk. - K., 1994. - NA IA NANU. - F. 12. - Op. 2. - № 750. - 345 s.

Litvinenko R.A. Pamyatniki pokrovskogo tipa na Severskom Donce [Burials of the Pokrovsk type in the Seversky Donets region] // Arheologicheskie vesti. SPb., 1995. - № 4. - C. 73-82.

Litvinenko R.A. Periodizaciya srubnyh mogil'nikov Severo-Vostochnogo Priazov'ya [Periodization of burial grounds of the Srubnaya culture of the North-East Azov region] // Drevnosti Severo-Vostochnogo Priazov'ya. - Doneck, 1999. - S. 4-23.

Litvinenko R.A. K istorii issledovaniya kurgannyh mogil'nikov v okrestnostyah Kamennyh Mogil [On the history of the study of burial mounds in the neighborhood of Stone Graves] // Drevnosti SeveroVostochnogo Priazov'ya. - Doneck, 1999a. - S. 98-101.

Lopatin V.A. Klassifikaciya keramiki Preobrazhenskogo poseleniya [Ceramic classification of the Preobrazhensk settlement] // AVES. - Vyp. 2. Saratov, 1991. - S. 42-52.

Mys'kov E.P. K probleme periodizacii pamyatnikov srubnoj kul'tury Nizhnego Povolzh'ya i VolgoDonskogo mezhdurech'ya [The problem of periodization of the complexes of the Srubnaya culture of the Lower Volga and Volga-Don interfluve] // SA. - 1991. - №4. - S. 145-163.

Otroshchenko V.V. Problemy periodyzatsii kultur serednoi ta piznoi bronzy Pivdnia Skhidnoi Yevropy (kulturno-stratyhrafichni zistavlennia) [Problems of periodization of cultures of Middle and Late Bronze Age of South Eastern Europe (cultural stratigraphic comparisons)]. - K., 2001. - $288 \mathrm{~s}$.

Otroshchenko V.V. Do genezy berezhnivsko-maivskoi zrubnoi kultury [To the genesis of the Berezhnovka-Maevka Zrubna culture] // Problemy hirnychoi arkheolohii: Materialy III-ho Kartamyskoho polovoho arkheolohichnoho seminaru (s. Novozvanivka Luhanskoi obl., 15.07.2004 r.). - Alchevsk, 2006. S. 18-30.

Probyiholova O.S. Naselennia nyzhnoi techii Siverskoho Dontsia ta Donetskoho kriazhu u zakliuchnyi period doby piznoi bronzy [Population of the lower reaches of the Seversky Donets and the Donetsk Ridge during the final period of the Late Bronze Age]: dys. ... kand. yst. nauk. - K., 2017. - NA IA NANU. - F. 12. Op. 2. $-314 \mathrm{~s}$.

Polidovich YU.B. O razmeshchenii keramicheskih sosudov $v$ srubnyh pogrebeniyah [About the location of ceramic pots in the burials of the Srubnaya culture] // AA. - Vyp. 6. - Doneck, 1997. - S. 163172.

Semenova A.P. Osnovnye tendencii razvitiya keramiki pokrovskogo i razvitogo etapov srubnoj kul'tury lesostepnogo Povolzh'ya (po dannym pogrebal'nyh pamyatnikov) [The main trends in the development of ceramics of the Pokrovsk and developed stages of the Srubnaya culture of the forest-steppe Volga region (based on materials of funerary monuments)] // Bronzovyj vek Vostochnoj Evropy: harakteristika kul'tur, hronologiya i periodizaciya. - Samara, 2001. - S. 273-279. 